http://dx.doi.org/10.11646/phytotaxa.132.1.1

\title{
New sources of taxonomic information for earthstars (Geastrum, Geastraceae, Basidiomycota): phenoloxidases and rhizomorph crystals
}

\author{
JUAN CARLOS ZAMORA ${ }^{1^{*}}$, FRANCISCO D. CALONGE ${ }^{1} \&$ MARÍA P. MARTÍN $^{1}$ \\ ${ }^{I}$ Real Jardín Botánico-CSIC. Pza. de Murillo 2. E-28014, Madrid, Spain. \\ *Corresponding author: jczamora@rjb.csic.es
}

\begin{abstract}
The taxonomic utility of two characters not previously used for identification of Geastrum species is evaluated. First, macrochemical spot tests with chemicals detecting phenoloxidase enzymatic activity (1-naphthol, guaiac gum, and syringaldazine), are performed. In addition, the usefulness of the crystalline deposits from the rhizomorphs, formed by calcium oxalate as monohydrate or whewellite, and dihydrate or weddellite, was evaluated. These features provide valuable data to distinguish some taxa difficult to separate using traditional morphology, such as G. lageniforme, $G$. saccatum, and G. triplex.
\end{abstract}

\section{Introduction}

Geastrum Persoon (1974: 85) : Persoon (1801: 131) is a genus of gasteroid Basidiomycota, widely known as earthstars due to the star-like shape of the mature fruitbodies (Sunhede 1989). The genus is world-wide distributed (Ponce de León 1968) and, according to Kirk et al. (2008), it consists of roughly 50 species. The taxonomy of the earthstars, as in many other macrofungi, has been traditionally based on morphological features of the basidiomata (Sunhede 1989). Traits such as the peristome type (fibrillose or sulcate), its delimitation in respect to the rest of the endoperidial body, the presence or absence of a stalk connecting the endoperidium and the exoperidium, the hygrometric behaviour of the exoperidial rays, and the structure of the mycelial layer, are the characters most frequently used for species identification and infrageneric subdivisions (Staněk 1958, Ponce de León 1968, Sunhede 1989, Calonge 1998). However, some species are rather difficult to identify, and misidentifications or mixed collections are commonly seen when revising herbarium specimens, as in the case of the G. congolense Dissing \& Lange (1962: 37) type material, where at least two different species were mixed (Sunhede 1986).

There are some particularly problematic groups that have been variously treated by different authors. For instance, G. pectinatum Persoon (1801: 132), G. striatum DC. in Lamarck \& de Candolle (1805: 267), and G. schmidelii Vittadini (1842: 13) are three species generally accepted as well-defined, but they were considered as a single, variable taxon by Ponce de León (1968). Geastrum morganii Lloyd (1901: 78) was reduced to a synonym of G. triplex Junghuhn (1840: 287) by Ponce de León (1968), considered conspecific with G. elegans Vittadini (1842: 15) by Calonge (1998), and treated as a well-defined, autonomous species by other authors such as Staněk (1958) and Sunhede (1989). Even more troublesome is the distinction of G. lageniforme Vittadini (1842: 16), G. saccatum Fries (1829: 16), and G. triplex, historically confused and treated as three different species by Staněk (1958), Sunhede (1989), and Calonge (1998), but not by other authors, such as Quélet (1886), Coker (1924), Cunningham (1944), and Ponce de León (1968). With the rise of molecular techniques, an even higher complexity of these taxa is coming to light, as shown in the G. triplex complex (Kasuya et al. 2012). Therefore, discovering and using new sources of taxonomic information may be desirable, at least as an attempt to clarify some of these difficult groups. 
Various macrochemical spot tests on the fruitbodies of different fungal groups have been used as taxonomic traits (Singer 1962). In particular, phenoloxidase spot tests are broadly used in Basidiomycota, with special emphasis on wood-rotting fungi, and a variety of reagents are available to detect such enzymes (Marr 1979). Guaiac gum is the most commonly used, and Bourquelot \& Bertrand (1896) presented the first extensive study on macrofungi, testing 44 genera of Basidiomycota and 4 of Ascomycota, while Gilbertson et al. (1975) employed it on about 60 genera of Basidiomycota. Singer (1962) showed its importance in the genus Inocybe (Fries 1821: 11) Fries (1863: 346), and it is traditionally used in the taxonomy of the genera Russula Persoon (1796: 100) (Sarnari 1998) and Cortinarius (Persoon 1801: 276) Gray (1821: 627) (Bidaud et al. 1994). Syringaldazine has been routinely used for detecting laccase in fungal cultures or fruitbodies (Harkin \& Obst 1973, Harkin et al. 1974), and its taxonomic value was already shown by Marr et al. (1986), who tested 222 species of 22 families of Basidiomycota. Recently, Tulloss \& Rodríguez-Caycedo (2011) reported on its use for the study of the genus Amanita Persoon (1794: 145) as well. Finally, 1-naphthol provided excellent results in the genus Agaricus Linnaeus (1753: 1171): Fries (1821: LVI) (Kerrigan 1986, Parra 2008), where most species in a particular section exhibit the same pattern of reactivity in the flesh, this character being highly congruent with molecular data (Parra 2008). Within the subclass Phallomycetidae, to which Geastrum belongs, phenoloxidase spot tests have been systematically used in the genus Clavariadelphus Donk (1933: 72) (Methven 1990). Sunhede (1989) performed several phenoloxidase spot tests on tissue cultures of 13 Geastrum species [including Trichaster melanocephalus (Czerniaiev 1845: 149)], finding a considerable variation on reactivity intensities with some reagents. Thus, this kind of chemical tests on fresh fruitbodies may provide some taxonomic information for Geastrum too.

On the other hand, the importance of studying the rhizomorph structure and crystals in certain fungi has been pointed out some years ago (Agerer 1999, Agerer \& Iosifidou 2004). According to Larsson (1994) crystal deposits widely occur among higher fungi. Keller (1985) studied the calcium oxalate crystals of several Aphyllophorales and found an unexpected morphological variation. The crystallography of the two types of calcium oxalate hydrates has been studied in detail by Frey-Wyssling (1981). Horner et al. (1995) found crystals of both calcium oxalate dihydrate (COD or weddelitte) and calcium oxalate monohydrate (COM or whewellite) on rhizomorphs of unidentified fungi, and such crystals have been used as valuable taxonomic characters in various genera, such as Skeletocutis Kotlaba \& Pouzar (1958: 103) (Keller 1979) and Trechispora P. Karsten (1890: 147) (Larsson 1994). Again, within Phallomycetidae, crystals on rhizomorphs have proven to be of high taxonomic interest, particularly in Clavariadelphus, where morphology and crystalline deposits on the mycelial hyphae are important features for subdividing the genus into subgenera and sections (Methven 1990). They are also very useful in other genera of the order Gomphales, where considerable morphological variation exists (Pérez-Daniëls 2002).

Concerning Geastrum, isolated bipyramidal crystals have been recorded in many species as an important part of the crystalline matter that covers endoperidial surfaces (Krisai \& Mrazek 1986, Sunhede 1989), and bipyramidal prisms were observed on the endoperidial surface of G. elegans by Krisai \& Mrazek (1986). However, as mentioned, those studies were not focused on the rhizomorphs but on the endoperidial surfaces. Agerer \& Beenken (1998) studied the rhizomorphs of $G$. fimbriatum Fries (1829: 16), noting the presence of crystals in clusters (druses), without doing a comparison with other species of the genus. They showed that rhizomorphs are composed of two types of hyphae. Generative hyphae, which are thin-walled, septate, clamped and clearly branched, constitute the rhizomorph core, but they are sometimes scarce or difficult to distinguish; clamps or septa are often swollen. Skeletal, thick-walled, aseptate, and sparsely branched hyphae compose the main part of the rhizomorph, and are especially abundant in the outer part. Agerer \& Iosifidou (2004) indicated the similarities of the rhizomorph structure of the Geastraceae [Geastrum and Myriostoma Desvaux (1809: 103)] with several members of the gomphoid clade, but did not report on differences among species of Geastraceae, or on crystal characteristics. Therefore, features of the rhizomorph crystalline matter in the earthstars are almost unexplored.

The aim of the present study was to investigate the value of two characters, not thoroughly studied in the genus Geastrum before, namely the reaction to phenoloxidase spot tests and the characteristics of the rhizomorphs, mainly with regard to the presence of crystals, and evaluating their use for taxonomic purposes. 


\section{Material and methods}

\section{Sampling}

A total of 110 new collections or herbarium specimens, representing 34 Geastrum species or species complexes, were studied. A summary of the specimens and herbarium vouchers is listed in the appendix. Specimens were determined mainly based on Staněk (1958), Ponce de León (1968), and Sunhede (1989), except for the species published after them [G. albonigrum Calonge \& M. Mata (2004: 332), G. ovalisporum Calonge \& Mor.-Arr. in Calonge et al. (2000: 273), G. parvistriatum J.C. Zamora \& Calonge (2007: 140), G. pleosporum Douanla-Meli in Douanla-Meli et al. (2005: 242), and G. setiferum Baseia in Baseia \& Milanez (2002: 136)] and a few others not included in the mentioned works [G. argentinum Spegazzini (1899: 193) and G. violaceum Rick (1906: 26)].

\section{Classical morphological traits}

The following morphological traits, broadly used in Geastrum classical taxonomy, were considered for comparison with the new characters studied here: peristome type (fibrillose/sulcate), peristome delimitation (delimited/not delimited), endoperidial connexion with the exoperidium (pseudostipitate/sessile), hygrometric behaviour of the exoperidial rays (hygrometric/not hygrometric), ability of the myceliar layer to encrust debris (encrusted/not encrusted), and anatomy of the mycelial layer (single-layered/double-layered). Those traits cover all the character sets used by Staněk (1958) to classify the different species of Geastrum into infrageneric subdivisions up to the subsection level, plus some additional characters that are useful for distinguishing most species in general keys (e.g., Sunhede 1989, Calonge 1998).

For the analysis of G. lageniforme, G. saccatum, and G. triplex samples, the following morphological characters, extracted from Staněk (1958) and Sunhede (1989), were used: anatomy of the mycelial layer (single-layered/double-layered), surface of the mycelial layer (felted/not felted, scaly/not scaly, cracked/not cracked), pseudoparenchymatous collar (present/absent), diameter of the endoperidial body $(>15 \mathrm{~mm} / \leq 15$ $\mathrm{mm}$ ), and basidiomata habit (robust/slender).

\section{Macrochemistry}

Macrochemical spot tests were made on the three exoperidial layers of fresh, but not over-moistened, well conserved basidiomata (i.e., with the pseudoparenchymatous layer not damaged). Spot tests were repeated twice per basidioma, on fresh cuts of different exoperidial rays. The following reagents were used: $5 \% 1$ naphthol in 70\% ethanol (Largent \& Benedict 1970), saturated solution (roughly 1-1.5\%) of guaiac gum in $70 \%$ ethanol (Sarnari 1998), and $0.1 \%$ syringaldazine in $95 \%$ ethanol (Harkin \& Obst 1973). Reaction results were annotated within the first 5 minutes after application of the reagent. Four different reaction intensities were considered: - (negative), $+/-$ (dubious), + (positive), and ++ (strongly positive). In total, 80 collections were used for these tests.

\section{Rhizomorph features}

Rhizomorphs were observed under light microscopy (LM) and scanning electron microscopy (SEM). Ninetyone collections were used for LM; small pieces of rhizomorphs were directly mounted in Hoyer's medium, and observed on a Reichert-Jung or a Jeulin light microscope, with $10 \times$ oculars and $40 \times$ or $100 \times$ objectives. For SEM, 12 air-dried samples, selected based on LM data trying to cover all the morphological variation observed, were mounted on a sample holder covered with double-sided adhesive tape, coated with pure gold in a Balzers SCD 004 sputter coater, and observed with a Hitachi S-3000N SEM, working at 15-25 kV. Crystals were assigned to COM or COD according to their habit (Frey-Wyssling 1981, Horner et al. 1995).

\section{Data encoding}

The recorded variables were encoded independently as presence/absence (1/0), assuming no transformations (Kitching et al. 1998). This codifying system allowed the encoding of variable characters in a more accurate 
way, including the variation observed especially in the phenoloxidases spot tests and morphological traits. Reaction results were reduced to "positive" or "negative" for codification purposes. Then, dubious reactions were disregarded when either a positive or negative reaction was also recorded, codifying only the positive or the negative reaction. When only dubious responses were recorded, they were codified as "negative". For rhizomorph traits, both the main and the secondary types of crystals were considered. We did not codify the subtypes of COD crystals separately because all of them usually appear mixed and, in addition, bipyramids and bipyramidal prisms are hardly distinguished under LM. Acanthocystidia presence was not used since the study of this character is likely to be incomplete. All matrices are available upon request.

\section{Phenetic analyses}

Data matrices were analyzed based on distance matrices, which were calculated using two different methods, i.e., Gower's distance dissimilarity matrices (Gower 1971) and total character difference matrices (Swofford 2003). Two sets of analyses were performed, one involving all the studied taxa (analyses 1-4), and other focused on specimens of three taxa particularly difficult to be distinguished, G. lageniforme s.l., G. saccatum s.l., and G. triplex s.l. (analyses 5-6). In both cases, analyses were repeated for the classical morphological character matrices (analyses 1 and 5), phenoloxidases (analysis 2) and rhizomorph matrices (analysis 3) separately, as well as for a combination of the two data matrices (analyses 4 and 6). Geastrum rufescens Persoon (1794: 86) : Persoon (1801: 134) was excluded in the general combined analysis because of lacking rhizomorph data, which are the main part of the informative data of the combined dataset. For the specific case of G. lageniforme s.l., G. saccatum s.l., and G. triplex s.l., only samples having all characters in each matrix were included in the analyses.

First, Gower's distance dissimilarity matrices were obtained with the R package "cluster" (Maechler et al. 2013), and clustering dendrograms were performed through the pvclust $\mathrm{R}$ package, using multiscale bootstrap resampling with 1000 bootstrap replicates to obtain the approximately unbiased (AU) $p$-values for branch supports, following Suzuki \& Shimodaira (2006). This method has been successfully used in previous studies involving small datasets with morphological data (Jiménez-Mejías \& Martinetto 2013). Groups are considered as well-supported when AU $p$-values are equal or higher than $95 \%$.

A second set of analyses based on total character difference distance matrices was conducted with PAUP* v4.0b10 (Swofford 2003), through PaupUp v1.0.3.1 graphical interface (Calendini \& Martin 2005). Phenograms were obtained using both Neighbour-Joining and tree bisection-reconnection as branch-swapping algorithm with the Fitch-Margoliash weighted least squares algorithm for the distance optimality criterion (Fitch \& Margoliash 1967), constraining branch lengths to be non-negative, and branches collapsing when maximum branch length is zero. To assess branch supports, 1000 non-parametric bootstrap searches (Felsenstein 1985) were performed with the "fast" stepwise-addition option. Groups are considered as wellsupported when bootstrap (BS) values are equal or higher than 70\% (Hillis \& Bull 1993). Phenograms were drawn with FigTree (Rambaut 2007).

\section{Taxonomic framework}

Our results were compared mainly with two different taxonomic treatments that included supraspecific subdivisions of the genus Geastrum. Ponce de León (1968) was chosen as a very synthetic taxonomic treatment (23 species worldwide), and Staněk (1958) because is a much more analytic taxonomic treatment (26 species, all but one from Europe). Sunhede's (1989) monograph will also be commented on for being the most comprehensive work on Geastraceae so far, agreeing with Staněk (1958) in most cases (24 Geastrum species in Europe).

\section{Results}

Only phenograms obtained through one of the mentioned methods (those from the R package based on Gower's distance matrices) are presented since all of them coincide in the major groups and particularly in the well-supported clusters, only differing in some minor unsupported groups. 

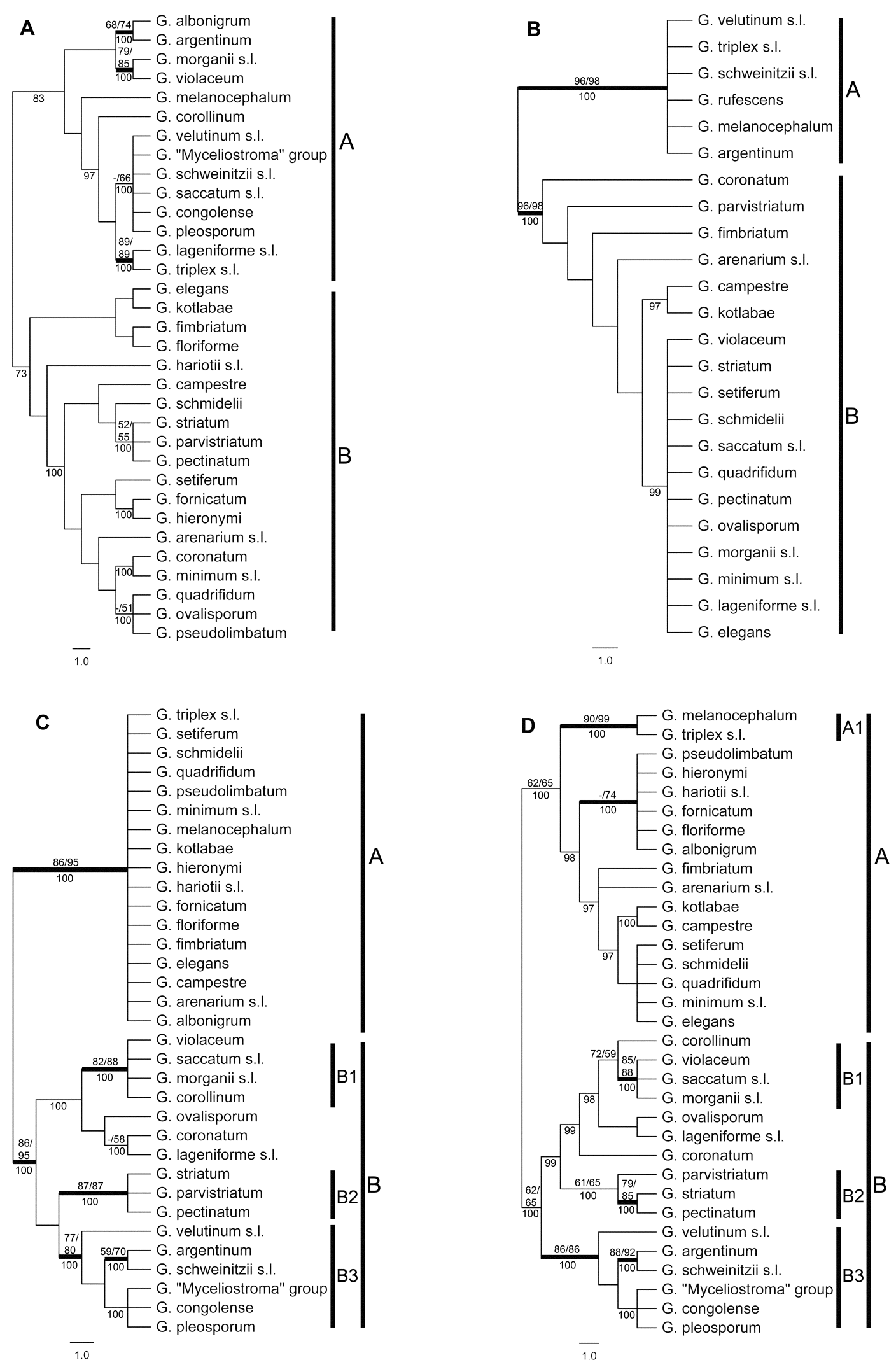

FIGURE 1. Phenograms of the studied taxa obtained from phenetic analyses based on distance matrices. A. Classical morphological traits phenogram (analysis 1). B. Phenoloxidases matrix phenogram (analysis 2). C. Rhizomorphs matrix phenogram (analysis 3 ). D. Combined dataset phenogram (analysis 4). Numbers above branches are BS values from Fitch-Margoliash based algorithm and Neighbour-Joining analyses, and numbers below branches are AU $p$-values from clustering analyses based on Gower's distance matrices. Branches are indicated in bold when at least two of the three branch supports are significant (BS $\geq 70 \%, A U \geq 95 \%$ ). 


\section{Classical morphological traits analyses}

The phenogram obtained from the classical morphological features of all taxa (Fig. 1A) clusters the included species in two low supported main groups, which coincide with the two sections defined by Staněk (1958), i.e., sect. Basimyceliata V.J. Staněk (1958: 781) (mycelial layer not encrusting debris, group A), and sect. Perimyceliata V.J. Staněk (1958: 780) (mycelial layer encrusting debris, group B). Only three pairs of species are clustered with significant branch supports, i.e., G. albonigrum with G. argentinum, both with not delimited, fibrillose peristomes, G. morganii s.l. with G. violaceum [Staněk's (1958) subsect. Plicostomata], which both have irregularly folded, not delimited peristomes, and G. lageniforme s.l. with G. triplex s.l., with singlelayered mycelial layers, distinctly delimited fibrillose peristomes, and sessile endoperidial bodies.

The morphological analysis of the G. lageniforme s.l., G. saccatum s.l., and G. triplex s.l. samples (Fig. 2A) reveals that all specimens of G. saccatum s.l. are grouped together (group E), and most samples of $G$. triplex s.l. and G. lageniforme s.l. also form more or less independent groups (A and D, respectively). However, two samples of G. lageniforme s.l. and three of G. triplex s.l. have an intermediate position (groups $\mathrm{B}$ and $\mathrm{C}$ ), corresponding to specimens that can be confused solely on classical morphological traits.

TABLE 1. Results from spot tests on fresh exoperidial layers of 24 Geastrum taxa. Numbers in brackets indicate the number of collections tested. Symbols separated by a middle dot are the extremes of variation observed. The exoperidial layers are indicated as ML (mycelial layer), FL (fibrous layer), PL (pseudoparenchymatous layer). Symbol meaning: negative, +/- dubious, + positive, ++ strongly positive. Untested treatments are indicated as "nd" (no data). Uniformly coloured cells are reactions considered "positive", streaked cells are variable reactions, and uncoloured cells are reactions considered "negative".

\begin{tabular}{|c|c|c|c|c|c|c|c|c|c|}
\hline \multirow{2}{*}{ Taxon } & \multicolumn{3}{|c|}{ 1-naphthol } & \multicolumn{3}{|c|}{ Guaiac gum } & \multicolumn{3}{|c|}{ Syringaldazine } \\
\hline & ML & FL & PL & ML & FL & PL & ML & FL & PL \\
\hline G. arenarium s.l. (4) & - & - & - & $-\cdot+$ & - & - & 1404 & - & - \\
\hline G. argentinum (5) & - & - & - & ++ & $-\cdot+/-$ & ++ & ++ & $-\cdot+/-$ & ++ \\
\hline G. campestre (1) & nd & nd & nd & + & - & - & nd & nd & nd \\
\hline G. coronatum (2) & - & - & - & + & $-\cdot+$ & $-\cdot+$ & $+\cdot++$ & 8 & 4 \\
\hline G. elegans (2) & - & - & - & $+\cdot++$ & - & - & + & - & - \\
\hline G. fimbriatum (9) & - & - & WHOS & ++ & $-\cdot+/-$ & $-\cdot+$ & ++ & - & $-\cdot+/-$ \\
\hline G. kotlabae (1) & nd & nd & nd & + & - & - & nd & nd & nd \\
\hline G. lageniforme s.l. (7) & - & - & - & $+\cdot++$ & - & - & ++ & - & - \\
\hline G. melanocephalum (4) & - & - & - & ++ & $-\cdot+/-$ & ++ & ++ & - & ++ \\
\hline G. minimum s.l. (2) & - & - & - & $+/-\cdot+$ & $-\cdot+/-$ & $-\cdot+/-$ & + & $-\cdot+/-$ & - \\
\hline G. morganii s.l. (2) & - & - & - & $+\cdot++$ & $-\cdot+/-$ & - & $+\cdot++$ & $-\cdot+/-$ & - \\
\hline G. ovalisporum (2) & - & - & - & $+/-\cdot+$ & - & - & $+/-\cdot+$ & - & - \\
\hline G. parvistriatum (2) & - & - & - & + & $-\cdot+$ & $-\cdot+$ & + & $-\cdot+/-$ & $-\cdot+/-$ \\
\hline G. pectinatum (1) & $-\cdot+/-$ & $+/-$ & $-\cdot+/-$ & + & - & $-\cdot+/-$ & + & - & - \\
\hline G. quadrifidum (2) & - & - & $+/-$ & + & - & $-\cdot+/-$ & $+/-\cdot+$ & - & $-\cdot+/-$ \\
\hline G. rufescens (3) & - & - & $-\cdot+1-$ & $+/-\cdot+$ & $-\cdot+/-$ & ++ & $+1-\cdot+$ & $-\cdot+/-$ & ++ \\
\hline G. saccatum s.l. (5) & - & - & - & $+\cdot++$ & $-\cdot+/-$ & - & $+\cdot++$ & $-\cdot+/-$ & - \\
\hline G. schmidelii (3) & - & - & - & $+/-\cdot+$ & $-\cdot+/-$ & - & $+/-\cdot+$ & - & - \\
\hline G. schweinitzii s.l. (1) & - & - & - & ++ & $+/-$ & ++ & ++ & $-\cdot+/-$ & ++ \\
\hline G. setiferum (1) & - & - & - & + & $+/-$ & - & + & $+/-$ & $-\cdot+/-$ \\
\hline G. striatum (2) & - & - & - & $+/-\cdot+$ & - & $-\cdot+/-$ & + & - & - \\
\hline G. triplex s.l. (9) & $-\cdot+/-$ & - & - & $+\cdot++$ & $-\cdot+/-$ & $+\cdot++$ & ++ & - & $+\cdot++$ \\
\hline G. velutinum s.l. (3) & - & - & - & ++ & $-\cdot+/-$ & ++ & ++ & $-\cdot+/-$ & ++ \\
\hline G. violaceum (5) & $-\cdot+1-$ & - & - & $+\cdot++$ & - & - & $+\cdot++$ & - & - \\
\hline
\end{tabular}



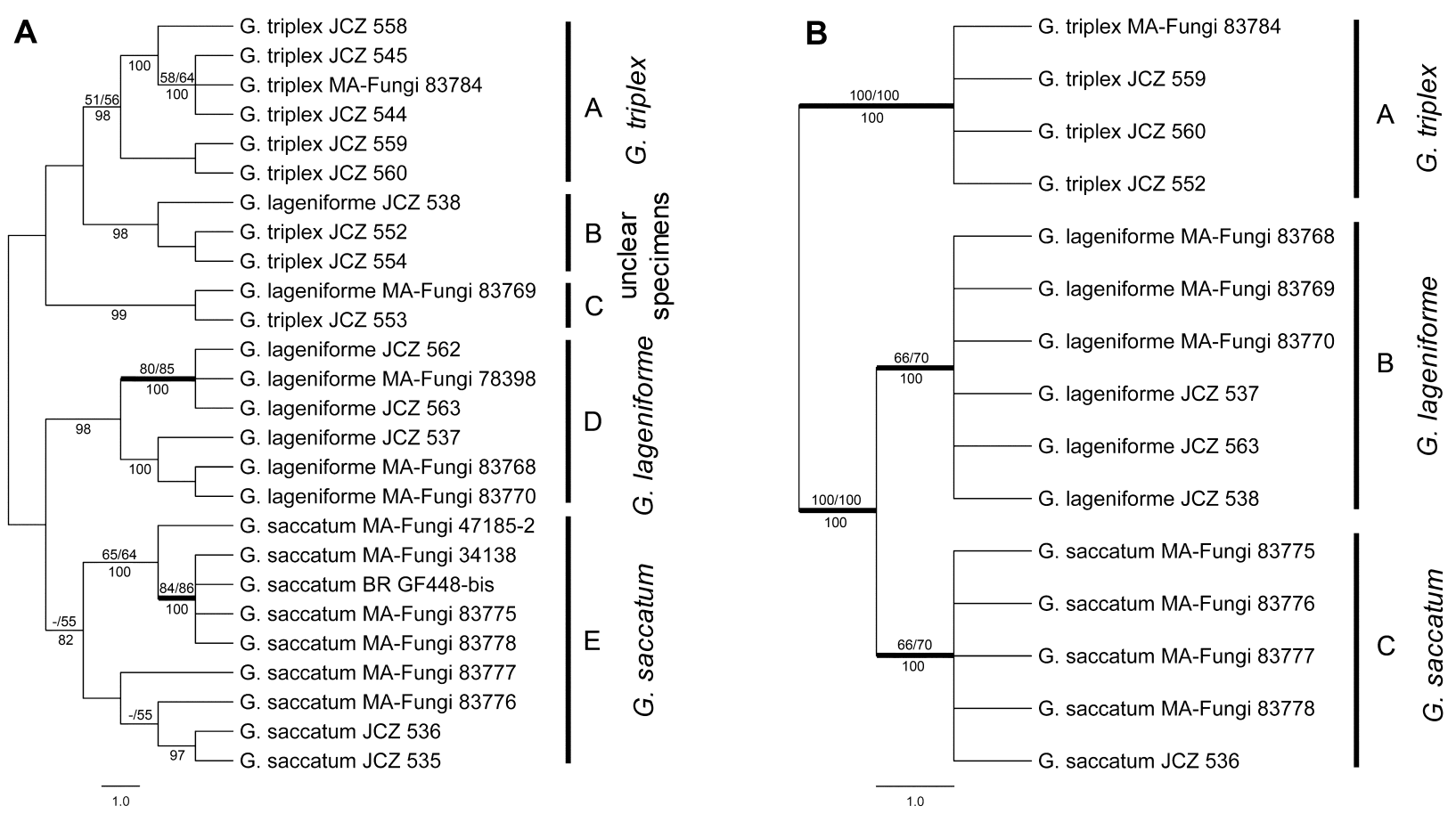

FIGURE 2. Phenograms of the G. lageniforme s.l., G. saccatum s.l., and G. triplex s.l. samples studied, obtained from phenetic analyses based on distance matrices. A. Classical morphological traits phenogram (analysis 5). B. Phenogram of the combined dataset from phenoloxidases spot tests and rhizomorph features matrices (analysis 6). Numbers above branches are BS values from FitchMargoliash based algorithm and Neighbour-Joining analyses, and numbers below branches are AU $p$-values from clustering analyses based on Gower's distance matrices. Branches are indicated in bold when at least two of the three branch supports are significant (BS $\geq 70 \%, \mathrm{AU} \geq 95 \%$ ).

\section{Phenoloxidases spot tests}

A summary of the tested taxa and their reaction results is presented in Tab. 1. With the exception of $G$. fimbriatum, 1-naphthol is unresponsive or nearly so in all exoperidial layers of all species tested. Even in the case of G. fimbriatum, only the pseudoparenchymatous layer often shows a positive to strongly positive reaction, but not all specimens react. Guaiac gum and syringaldazine give similar patterns, being positive (sometimes faintly) on the mycelial layer, negative or dubious on the fibrous layer, and often negative on the pseudoparenchymatous layer. However, the pseudoparenchymatous layer exhibits a positive to strongly positive reaction with the latter two reagents in the following species: Geastrum argentinum, $G$. melanocephalum (Czern.) V.J. Staněk (1956: 22), G. rufescens, G. schweinitzii (Berkeley \& M.A. Curtis 1853: 279) Zeller (1948: 649) s.l., G. triplex s.l., and G. velutinum Morgan (1895: 38) s.l. In three species, G. fimbriatum, G. coronatum Persoon (1801: 132), and G. parvistriatum, the reaction is variable (negative, dubious, or positive). The remaining species show a constantly negative reaction on the pseudoparenchymatous layer: Geastrum arenarium Lloyd (1902: 28), G. campestre Morgan (1887: 1027), G. elegans, G. kotlabae V.J. Staněk (1958: 474, 784), G. lageniforme s.l., G. minimum Schweinitz (1822: 58), G. morganii s.l., G. ovalisporum, G. pectinatum, G. quadrifidum Persoon (1794: 86): Persoon (1801: 133), G. saccatum s.l., G. schmidelii, G. setiferum, G. striatum, and G. violaceum.

Analysis 2 (Fig. 1B) shows a phenogram formed by two well-supported groups, the first one (group A) including all species with a positive reaction with syringaldazine and guaiac gum on the pseudoparenchymatous layer, and the second one (group B) grouping species with negative or variable reaction on that exoperidial layer. Within group $B$, species with a variable reaction with syringaldazine and guaiac gum on the pseudoparenchymatous layer (G. coronatum, G. parvistriatum, and G. fimbriatum) are more or less separated to the core formed by taxa with negative reactions. However, this grouping is not wellsupported. 


\section{Rhizomorph features}

When present, calcium oxalate crystals normally cover the most external skeletal hyphae, which may be undifferentiated from the rest or protruding and even dilated (treated here as "cystidioid cells" or "cystidioid elements", see below). Three main types of crystalline matter appear, and two cystidioid elements. The different morphological types of rhizomorph crystals and cystidioid cells found in Geastrum species are indicated in Tab. 2. Transitions or mixed aggregates may occur.

TABLE 2. Distribution of the main type of rhizomorph crystals and cystidioid cells in 33 Geastrum taxa. Numbers in brackets after species names indicate the number of collections studied. When a secondary type of rhizomorphs crystals is constantly present (not just sporadically) it is indicated in brackets. Subscripts refer to the subtype of crystals in the elongated non-faceted forms ( $1=$ acicular, $2=$ horn-like $)$ and rhomboidal oblique prisms $(1=$ narrow, $2=$ coarse $)$, as well as to the shape of crystalliferous cystidioid cells $(1=$ narrow and cylindrical, $2=$ dilated $)$, as mentioned in the text. The three subtypes of bipyramidal crystals normally appear mixed and are not separated here.

\begin{tabular}{|c|c|c|c|c|c|}
\hline \multirow[b]{2}{*}{ Taxon } & \multicolumn{3}{|c|}{ Crystalline matter } & \multicolumn{2}{|c|}{ Cystidioid elements } \\
\hline & $\begin{array}{l}\text { Elongated non- } \\
\text { faceted forms }\end{array}$ & $\begin{array}{c}\text { Rhomboidal } \\
\text { oblique prisms }\end{array}$ & $\begin{array}{c}\text { Bipyramidal } \\
\text { crystals }\end{array}$ & $\begin{array}{l}\text { Crystalliferous } \\
\text { "cystidia" }\end{array}$ & Acanthocystidia \\
\hline G. albonigrum (2) & & & + & & + \\
\hline G. arenarium s.l. (2) & & & + & & \\
\hline G. argentinum (5) & & $\left(++_{2}\right)$ & + & $+_{1}$ & + \\
\hline G. campestre (1) & & & + & & \\
\hline G. congolense (1) & & $+_{2}$ & & $+_{1}$ & + \\
\hline G. corollinum (1) & $+_{1}$ & & & & \\
\hline G. coronatum (2) & $+_{2}$ & & & & + \\
\hline G. elegans (1) & & & + & & \\
\hline G. fimbriatum (8) & & & + & & + \\
\hline G. floriforme (1) & & & + & & \\
\hline G. fornicatum (1) & & & + & & \\
\hline G. hariotii s.l. (1) & & & + & & \\
\hline G. hieronymi (1) & & & + & & \\
\hline G. kotlabae (1) & & & + & & \\
\hline G. lageniforme s.l. (7) & $+_{2}$ & & & & + \\
\hline G. melanocephalum (2) & & & + & & \\
\hline G. minimum s.l. (1) & & & + & & \\
\hline G. morganii s.l. (3) & $+_{1}$ & & & & + \\
\hline G. ovalisporum (1) & $\left(++_{2}\right)$ & & + & & \\
\hline G. parvistriatum (2) & $\left(+_{2}\right)$ & & + & $+_{1}$ & + \\
\hline G. pectinatum (1) & $\left(++_{2}\right)$ & & + & $+_{1}$ & \\
\hline G. pleosporum (1) & & $+_{2}$ & & $+_{1}$ & + \\
\hline G. pseudolimbatum (1) & & & + & & \\
\hline G. quadrifidum (2) & & & + & & \\
\hline G. saccatum s.l. (9) & $+_{1}$ & & & & + \\
\hline \multicolumn{6}{|l|}{ G. schmidelii (3) } \\
\hline G. schweinitzii s.l. (7) & & $++_{2}$ & $(+)$ & $+_{1}$ & + \\
\hline G. setiferum (1) & & & + & & \\
\hline G. sp. (Myceliostroma) (1) & & $+_{2}$ & & $+_{1}$ & + \\
\hline G. striatum (4) & $\left(+_{2}\right)$ & & + & $+_{1}$ & + \\
\hline G. triplex s.l. (4) & & & + & & + \\
\hline G. velutinum s.l. (6) & & $+_{1(2)}$ & & $+_{2}$ & + \\
\hline G. violaceum (6) & $+_{1}$ & & & & + \\
\hline
\end{tabular}




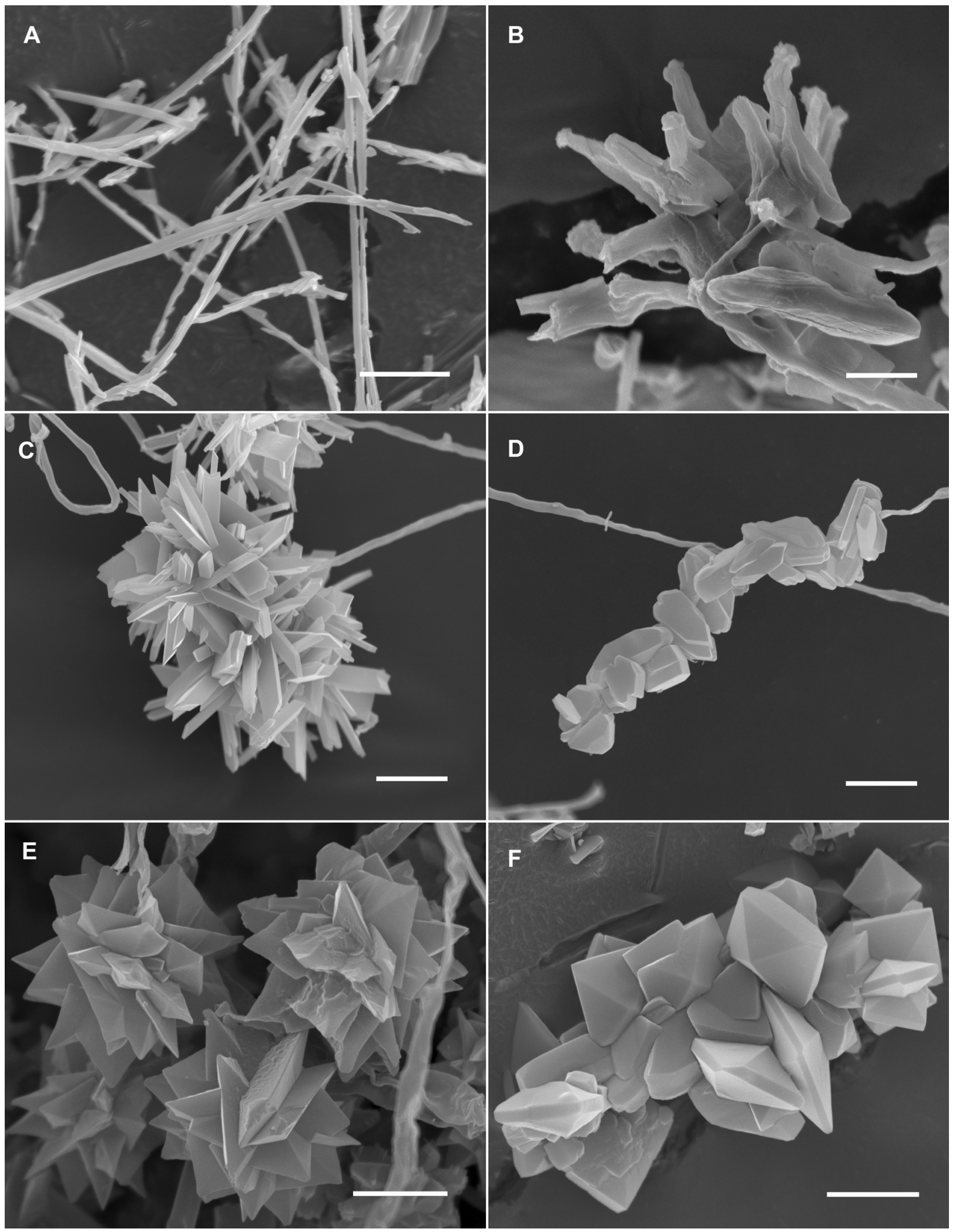

FIGURE 3. Morphological variation of rhizomorph crystals in Geastrum. A. Geastrum saccatum (herb. J.C. Zamora 535): Acicular crystals in an irregular arrangement. B. Geastrum lageniforme (herb. J.C. Zamora 537): Horn-like crystals grouped on an irregular candelabrum-like structure. C. Geastrum velutinum (MA-Fungi 83786): Narrow oblique prisms covering a dilated cystidioid element. D. Geastrum schweinitzii (MA-Fungi 83779): Coarser and more irregular oblique prisms covering a narrow cystidioid element. E. Geastrum triplex (herb. J.C. Zamora 552): Druses or rose-like aggregates of bipyramidal crystals. F. Geastrum argentinum (MA-Fungi 82604): Bipyramids and very short bipyramidal prisms. Scale bars $=5 \mu \mathrm{m}$. 
The first type of crystals are elongated, non-faceted forms of COM or whewellite (monoclinic system), with two main subtypes. In Fig. 3A raphides or acicular crystals are shown, being more or less filiform or with a "needle-like" appearance, not conspicuously thickened or narrowed to any one of the tips. They often form irregular powdery masses, but are sometimes grouped in arachnoid or substellate structures following a radial pattern. This subtype is present in G. corollinum (Batsch 1783: 151) Hollós (1904: 57), G. morganii s.l., G. saccatum s.l. (including some basidiomata present in the G. congolense type material, see discussion), and $G$. violaceum. Fig. 3B shows horn-like crystals, which are stouter, conspicuously thickened towards their bases, and often fused forming candelabrum-like structures. Sometimes, those crystals are rather long and thin, being a transition of the previous subtype, and then they also form more or less arachnoid or substellate structures. They are characteristic of G. coronatum and G. lageniforme s.l., but can appear as a secondary type in $G$. ovalisporum, G. parvistriatum, G. pectinatum, and G. striatum.

The second crystal type are rhomboidal oblique prisms of COM or whewellite (monoclinic system), with two subtypes. They are present in a few species of Geastrum and are often grouped covering protruding hyphae that can be distinguished as crystalliferous cystidioid elements (see below). These prisms are either narrow and well-formed (Fig. 3C), as in G. velutinum s.l., or coarser and somewhat irregular (Fig. 3D), as in part of the G. congolense type material (including one unidentified species of the "Myceliostroma" group, see discussion), G. pleosporum, and G. schweinitzii s.l. Some old crystalliferous cystidioid cells of G. velutinum s.l. are often covered by coarse crystals as well. In G. argentinum, coarse and irregular oblique prisms are present as a secondary type.

The third type of crystals are the bipyramidal crystals, formed by COD or weddellite (tetragonal system), with three subtypes. Fig. 3E shows druses or rose-like aggregates, which appear when penetration twins of bipyramidal crystals are formed following a more or less radiate pattern. The result is a rounded aggregate with protruding vertices. It is the most common type in the genus Geastrum (see Tab. 2). Isolated bipyramidal crystals are shown in Fig. 3F, being rarely dominant on the rhizomorphs, but often appearing when the next subtype is present. Finally, Fig. 3F also shows bipyramidal prisms, which are tetragonal prisms with pyramids as bases, and always appear mixed with one or the two previous subtypes. The rectangular faces of the prism are often very short, being very difficult or impossible to distinguish this subtype from the pure bipyramidal crystals under the light microscope.

On the other hand, some of the crystal morphotypes in Geastrum may be found isolated or grouped covering more or less cylindrical structures. In many species, those groupings are rather irregular and inconstant, being an undifferentiated part of the structure of the rhizomorph, or just isolated hyphae with a particularly dense crystal covering. This arrangement is common, e.g., in species with rose-like aggregates of bipyramidal crystals. However, in a small number of species, a more or less regular arrangement of crystals on some hyphae, which may be slightly dilated and, often, protruding from the rhizomorph surface can be identified. The crystals present on those regular structures are normally prism-shaped, either long and narrow or short and thick (Figs. 3C, D), more rarely bipyramidal to rose-like. We refer to these structures as crystalliferous cystidioid cells or cystidioid elements, occurring in G. argentinum, G. congolense, $G$. parvistriatum, G. pectinatum, G. pleosporum, G. schweinitzii s.l., G. striatum, G. velutinum s.l., and one unidentified species of the "Myceliostroma" group (Tab. 2). In particular, in G. velutinum s.l. these cystidioid elements are so conspicuous, dilated and clearly protruding from the rhizomorph surface, that they may be interpreted as true cystidia.

Another type of cystidioid cells are the acanthocystidia, having been found in the following species: Geastrum albonigrum, G. argentinum, G. congolense, G. coronatum, G. fimbriatum, G. lageniforme s.l., G. morganii s.l., G. parvistriatum, G. pleosporum, G. saccatum s.l., G. schweinitzii s.l., G. striatum, G. triplex s.l., G. velutinum s.l., G. violaceum, and one unidentified species of the "Myceliostroma" group. However, they often appear in low numbers and can be difficult to observe.

Analysis 3 (Fig. 1C) gives a phenogram with two main, well-supported groups (A and B). Group A includes all taxa with exclusively COD crystals, while in group B COM crystals are present either as the main type or as a secondary type. Group B has a more complex structure and three well-supported subgroups can be 
defined. Subgroup B1 contains the species without crystalliferous cystidioid cells and with acicular crystals (G. corollinum, G. morganii s.l., G. saccatum s.l., and G. violaceum). Subgroup B2 includes those species with crystalliferous cystidioid cells, COD as the main type of crystals, and the presence of horn-like COM crystals (G. parvistriatum, G. pectinatum, G. striatum). Subgroup B3 groups the species with crystalliferous cystidioid cells and rhomboidal oblique prisms of COM crystals (G. argentinum, G. congolense, G. pleosporum, one unidentified species of the "Myceliostroma" group, G. schweinitzii s.l., and G. velutinum). The positions of G. coronatum, G. lageniforme s.l., and G. ovalisporum are not well-supported by BS, but G. coronatum and G. lageniforme s.l. are clustered with a high AU $p$-value.

\section{Combined datasets analyses}

The phenogram for the combined analyses of phenoloxidases and rhizomorph data (analysis 4, Fig. 1D) is rather similar to that of the rhizomorph dataset alone (Fig. 1C). Two main groups are recovered; group A includes species with COD as the only type of crystals, and group B contains species where COM crystals are present These two groups are, however, not well-supported. Within group A, G. triplex s.l. and G. melanocephalum are particularly well-separated from the other species, with high BS (90\%/99\%) and AU $p$ values (100\%) (subgroup A1). Group B is divided into three subgroups receiving some branch support. Subgroup B1 is only partially supported by BS and is the group of species without crystalliferous cystidioid cells and with acicular COM crystals (G. corollinum, G. morganii s.l., G. saccatum s.l., and G. violaceum). Subgroup B2 is formed by species with crystalliferous cystidioid cells and both COD and COM (horn-like) crystals (G. parvistriatum, G. pectinatum, and G. striatum); it is recovered with low BS support (61\%/65\%) but high AU $p$-value (100\%), while the relationship of G. pectinatum with G. striatum is well-supported by all analyses. Finally, subgroup B3 is recovered with high BS (86\%/86\%) and AU $p$-values $(100 \%)$, clustering all the species with crystalliferous cystidioid cells and rhomboidal oblique prisms of COM crystals $(G$. argentinum, G. congolense, G. pleosporum, one unidentified species of the "Myceliostroma" group, $G$. schweinitzii s.l., and G. velutinum s.l.). Again, the positions of G. coronatum, G. lageniforme s.l., and G. ovalisporum are not well-supported.

In the analysis of 15 specimens of G. lageniforme s.l., G. saccatum s.l., and G. triplex s.l., for which information was recorded for both phenoloxidases and rhizomorphs (analysis 6, Fig. 2B), each species is segregated in its own, independent group.

\section{Discussion}

The taxonomic utility of phenoloxidases spot tests

Despite the excellent results that 1-naphthol provided in the study of some fungal groups, such as Agaricus (Parra 2008), in Geastrum it seems to have little taxonomic significance. As previously noted, only $G$. fimbriatum often shows a positive to strongly positive reaction on the pseudoparenchymatous layer. However, even this species may exhibit very high variability and some specimens do not react at all, despite being fresh and in good condition. Therefore, it should probably be discarded as useful for taxonomy, at least directly used on fresh basidiomata.

On the other hand, both guaiac gum and syringaldazine reactions are more distinct between different taxa, rather consistent within the same species and, therefore, probably of more interest. According to our results, both reagents react similarly, with positive reactions on the mycelial layer but varying considerably on the pseudoparenchymatous layer. The interpretation of the reaction on the fibrous layer is often difficult, since it is almost impossible to clean it completely from remnants of the surrounding layers. The variation of the spot tests on the pseudoparenchymatous layer is the critical point that made the use of these reagents valuable. In most species the reaction is null to almost null, but in some it is clearly and constantly positive, i.e., $G$. melanocephalum, G. triplex s.l., G. argentinum, G. rufescens, G. schweinitzii s.l., and G. velutinum s.l. Some of these species are taxonomically problematical or difficult to distinguish based on classical morphological traits (Ponce de León 1968, Sunhede 1986, Sunhede 1989). 
Geastrum morganii and G. triplex, which can be differentiated through classical morphological traits such as the mycelial layer and the peristome (analysis 1, Fig. 1A), but were considered synonymous by Ponce de León (1968), are also placed in different groups by phenoloxidases spot tests (analyses 2 and 4, Figs. 1B, D). These results agree with the taxonomic treatment of Staněk (1958) and Sunhede (1989), and not with Ponce de León (1968).

Syringaldazine has several advantages compared to guaiac gum, such as not auto-oxidizing in contact with air, and also its higher reproducibility, because it is a chemically pure substance instead of a natural product of variable composition (Harkin \& Obst 1973). Taking all these data into account, syringaldazine is the best reagent of the three tested for taxonomy of the genus Geastrum. However, the use of guaiac gum is still useful for detection of phenoloxidases, other than laccase.

\section{Rhizomorph features: an unexpected morphological variation with taxonomic meaning}

Several studies have revealed the presence of calcium oxalate crystals in Geastrum basidiomata (Horner et al. 1985, Whitney \& Arnott 1986, Krisay \& Mrazek 1986). According to the crystal shape, we can distinguish crystals of the tetragonal system, formed by COD or weddellite, as well as crystals of the monoclinic system, formed by COM or whewellite (Horner et al. 1985, Horner et al. 1995). According to our data, such variation is not related to the type of substrate, since some of the species with different types of crystals have been found growing together, such as G. arenarium, G. coronatum, and G. lageniforme on sandy, siliceous soil, or $G$. lageniforme, G. minimum, and G. parvistriatum on clayey, calcareous soil, and every species shows the same type of crystals, regardless of the habitat. Larsson (1994) speculated that crystal shape in different species might be a genetically controlled phenomenon, and our results on Geastrum lead us to agree with that opinion, although we cannot confirm the genetic basis for constancy.

Many of the species show druses or rose-like aggregates of bipyramidal crystals on rhizomorph surfaces (COD), often mixed with some isolated bipyramidal crystals or bipyramidal prisms. Rose-like aggregates were also found in various species of the order Gomphales (Pérez-Daniëls 2002), and on rhizomorphs of Geastrum fimbriatum (Agerer \& Beenken 1998). However, there are some groups with rather characteristic or even unique types of crystals that might be of taxonomic interest.

Rhomboidal oblique prisms (COM) are one of the less common types, and are only found as the main type in G. congolense, G. pleosporum, G. schweinitzii s.l., G. velutinum s.l., and one unidentified species of the "Myceliostroma" group. They are also present as a secondary type in G. argentinum. The mentioned species with rhomboidal oblique prisms are, in addition, some of the few species with a clearly positive reaction with guaiac gum and syringaldazine on the pseudoparenchymatous layer. These species have been considered as closely related by some authors, and even grouped in a distinct subgenus named Myceliostroma (Ponce de León 1968), which includes most of the lignicolous Geastrum species. Furthermore, they have the best developed crystalliferous cystidioid elements (particularly in G. velutinum s.l.) of all the studied species. In agreement with Ponce de León (1968), our data suggest that those species are probably related.

The G. saccatum s.l. and G. morganii s.l. groups, G. violaceum, and G. corollinum, all have acicular crystals (COM), often very abundant and forming powdery masses. Needle-like crystals were previously observed in the rhizomorphs of some species of the order Gomphales (Pérez-Daniëls 2002), but they are not present in any other Geastrum species and, together with the rest of morphological characteristics, it may also indicate that the cited taxa are related. Analyses 3 and 4 (Figs. 1C, D) support both this view and the taxonomic treatment of Staněk (1958) and Sunhede (1989), considering G. morganii as different from G. triplex, while Ponce de León (1968) considered these taxa conspecific. However, only Sunhede (1989) suggested the similarities between G. morganii and G. saccatum, commenting under G. morganii: "The species could habitually be described as a G. saccatum Fr. with plicate peristome". The analysis based on classical morphological traits (analysis 1, Fig. 1A) recovers G. morganii and G. violaceum in the same group, but $G$. saccatum and G. corollinum are not grouped with them, agreeing with Staněk (1958).

Although acanthocystidia have been found in some of the studied taxa, we cannot consider them absent in the remaining species, because they are often present in low number and can be easily overlooked. 
Acanthocystidia were first observed by Agerer \& Beenken (1998), who stated that they are also typical of other members of subclass Phallomycetidae, such as some Ramaria Fries (1838: 571) ex Bonorden (1851: 166) species and Gomphus clavatus (Persoon 1795:21) Gray (1821:638). They have been seen in Myriostoma too, and are probably characteristic of most species of the gomphoid clade (Agerer \& Iosifidou 2004). Further research is needed to evaluate their utility for earthstar taxonomy.

Interestingly, G. melanocephalum and G. triplex are always placed in the same group when using phenoloxidase and rhizomorph data, and they are particularly well-separated from the rest of the species when both datasets are combined (analysis 4, Fig. 1D). Staněk (1958) considered these species to be very close based on traits of the mycelial layer and immature basidiomata, and Kasuya et al. (2012) confirmed by molecular data that the European G. triplex and G. melanocephalum are closely related. By contrast, Ponce de León (1958) treated them in different subgenera, and Sunhede (1989) kept G. melanocephalum in the genus Trichaster Czerniaiev (1845: 149) instead of Geastrum. Our results agree with Staněk (1958) and with the phylogenetic analyses of Kasuya et al. (2012).

Other evidence of the taxonomic significance of crystal morphology was found when revising the type specimen of $G$. congolense, which consists of about 22 basidiomata (some reduced to a few fragments). As mentioned before, one group of basidiomata bears prism-shaped crystals grouped on crystalliferous cystidioid elements, while another group of basidiomata shows acicular crystals, lacking any kind of crystalliferous cystidioid cells. This collection was previously studied by Sunhede (1986). He suggested the existence of two species intermixed ( $G$. congolense and one species of the G. saccatum group), mainly based on the presence or absence of a stipe in the exoperidium, but also considering some features of the mycelial layer. However, although all stipitate basidiomata have prism-shaped crystals, they are also found in some of the non-stipitate fruitbodies. This first group is heterogeneous, the stipitate basidiomata (four complete and five sectioned or fragmented, expanded and unexpanded fruitbodies) have, in addition, a rather thick (0.4-0.8 mm thick), ochraceous brown, and tufted mycelial layer and belong to G. congolense s.str; the non-stipitate basidiomata (three complete and three sectioned, all unexpanded fruitbodies) have a thinner (0.2-0.5 mm thick), yellowish ochraceous, and not tufted mycelial layer, and belong to a species of the "Myceliostroma" group, not of the $G$. saccatum group as was stated by Sunhede (1986). The remaining non-stipitate basidiomata with acicular crystals (six complete, all expanded fruitbodies and fragments of another one) have, in addition, an even thinner (0.1-0.4 mm thick) and ochraceous to cream-coloured mycelial layer, and belong to our concept of $G$. saccatum s.l. Therefore, we conclude that there are three different species intermixed in the type collection of G. congolense and not only two as was suggested by Sunhede (1986).

\section{Geastrum lageniforme, G. saccatum, and G. triplex: a long standing problem, an easy solution}

Misidentifications concerning G. lageniforme, G. saccatum, and G. triplex are probably the most important species-level taxonomic problem in Geastrum, which has not been resolved yet based on classical morphological traits. While the distinction of G. saccatum can be made through macro- and micromorphology of the mycelial layer (double-layered, with a felted surface), some big and robust G. lageniforme specimens can be easily confused with small and slender G. triplex specimens as shown in analysis 5 (Fig. 2A). We have not found any reliable traits in the literature to distinguish these "morphologically intermediate" specimens. Those problems led some authors to consider G. lageniforme and G. triplex as conspecific (Coker 1924, Cunningham 1944, Ponce de León 1968). Even in the case of G. saccatum, the correct interpretation of the mycelial layer usually requires some experience, especially to separate it from G. lageniforme, and the habit of both species is so close that misidentifications are common (Sunhede 1989). Quélet (1886) considered $G$. saccatum and G. lageniforme as a single species.

However, based on the new characters used here, the three taxa can be separated with confidence. The utility of guaiac gum and syringaldazine has been proven with several Spanish samples of G. lageniforme, $G$. saccatum and G. triplex sensu Staněk (1958) and Sunhede (1989), three rather common species which are sometimes found growing together. The reactions with both guaiac gum and syringaldazine on the pseudoparenchymatous layer of these species are of high utility, no negatives having been detected in $G$. 
triplex or positives in G. lageniforme and G. saccatum, when basidiomata are in good condition and not overmoistened. Geastrum triplex is well-separated from G. lageniforme and G. saccatum in analyses 2, 4, and 6 (Figs. 1B, 1D, 2B). Since G. lageniforme and G. saccatum show the same reactivity patterns, we need additional traits to distinguish them.

However, through rhizomorph crystal morphology the three species can be easily separated (Fig. 3). Both analyses 3, 4, and 6 recovered them as different (Figs. 1C, 1D, 2B), agreeing again with Staněk (1958) and Sunhede (1989), and not with Ponce de León (1968). Since rhizomorphs are easily preserved in dried specimens, and crystals seem to be not significantly altered, crystal morphology can be studied in herbarium specimens irrespective of their age, and are of high value during taxonomic revisions.

\section{Conclusions}

Two of the phenoloxidase spot tests presented here provide useful taxonomic information, because they are rather distinct between different species and quite consistent within the same species. The best of the three reagents tested was syringaldazine, mainly due to its stability and reproducibility. However, since syringaldazine detects specifically laccase, the use of gum guaiac, which reacts with a larger spectrum of phenoloxidades, may also be desirable.

Rhizomorph crystals also show high interspecific variation, being almost invariant in different collections of the same species. In addition, those crystals are well-conserved in herbarium specimens. Thus, we consider them of high value for taxonomic purposes, and they may be used to characterize and differentiate some species or species groups. Special care should be taken when sampling earthstars in the field, trying to collect a small portion of rhizomophs for each specimen.

\section{Acknowledgements}

We are grateful to all collectors and curators of herbaria BAFC, BR, MA-Fungi, MEL, and UPS for making available the studied material. We thank also those who contributed by providing chemical reagents, especially L.A. Parra, I. Olariaga, S. Serrano, and J. Muñoz. We are indebted to P.P. Daniëls for his encouragement to study rhizomorph crystals and to Y. Ruiz for her invaluable help with the SEM. We also acknowledge J.V. Sandoval-Sierra and P. Jiménez-Mejías for their valuable comments, especially concerning the analytical part. The first author is indebted to all who assisted him during his stays in Sweden (S. Sunhede, S. Ekman, S. Rymman, M. Myrdal, K. Hansen, and I. Olariaga in particular), and Argentina (especially L. Papinutti, F. Kuhar, V. Castiglia, G. Rolón, E. Grassi, S. Suaza, A. Romero, A. Arambarri (†), and E. García). The first author also thanks the Consejo Superior de Investigaciones Científicas (CSIC, Spain) for supporting the work with the grant JAE-Predoc (2010). M. Glenn (Seton Hall Univ., New Jersey, USA) is thanked for

English grammatical correction.

\section{References}

Agerer, R. (1999) Never change a successful principle: the evolution of Boletales s.l. (Hymenomycetes, Basidiomycota) as seen from below ground features. Sendtnera 6: 5-91.

Agerer, R. \& Beenken, L. (1998) Geastrum fimbriatum Fr. + Fagus sylvatica L. Descriptions of Ectomycorrhizae 3: 1318.

Agerer, R. \& Iosifidou, P. (2004) Rhizomorph structures of Hymenomycetes: a possibility to test DNA-based phylogenetic hypotheses? In: R. Agerer, M. Piepenbring \& P. Blanz (eds.) Frontiers in Basidiomycote Mycology. IHW-Verlag, Berchtesgaden, pp. 249-302.

Batsch, A.J.G.K. (1783) Elenchus fungorum. Halae, Magdeburgicae, 183 pp.

Baseia, I.G. \& Milanez, A.I. (2002) Geastrum setiferum (Gasteromycetes): a new species with a setose endoperidium. 
Mycotaxon 84: 135-139.

Berkeley, M.J. \& Curtis, M.A. (1853) Exotic fungi from the Schweinitzian Herbarium, principally from Surinam. Journal of the Academy of Natural Sciences of Philadelphia 2: 277-294.

Bidaud, A., Moënne-Loccoz, P. \& Reumaux, P. (1994) Atlas des Cortinaires: clé générale des sous-genres, sections, sous-sections et series. Éditions Fédération Mycologique Dauphiné-Savoie, Annecy-Seynod, 102 pp.

Bonorden, H.F. (1851) Handbuch der allgemeinen Mykologie. Schweizerbart'sche Verlagshandlung, Stuttgart, 336 pp.

Bourquelot, E. \& Bertrand, G. (1896) Les ferments oxydants dans les Champignons. Bulletin de la Société Mycologique de France 12: 18-26.

Calendini, F. \& Martin, J.-F. (2005) PaupUp v1.0.3.1 A free graphical frontend for PAUP* Dos software. Available from http://www.agro-montpellier.fr/sppe/Recherche/JFM/PaupUp (accessed: 1 Jul 2012).

Calonge, F.D. (1998) Gasteromycetes. I. Lycoperdales, Nidulariales, Phallales, Sclerodermatales, Tulostomales. Flora Mycologica Iberica 3: 1-271.

Calonge, F.D. \& Mata, M. (2004) A new species of Geastrum from Costa Rica and Mexico. Boletín de la Sociedad Micológica de Madrid 28: 331-335.

Calonge, F.D., Moreno-Arroyo, B. \& Gómez, J. (2000) Aportación al conocimiento de los Gasteromycetes, Basidiomycotina de Bolivia. Geastrum ovalisporum sp. nov. Boletín de la Sociedad Micológica de Madrid 25: 271276.

Coker, W.C. (1924) The geasters of the United States and Canada. Journal of the Elisha Mitchell Scientific Society 39: 170-224.

Cunningham, G.H. (1944) The Gasteromycetes of Australia and New Zealand. Bibliotheca Mycologica 67: 1-239.

Czerniaiev, B.M. (1845) Noveaux cryptogames de l'Úkraine et quelques mots sur la flore de ce pays. Bulletin de la Société Impériale des Naturalistes de Moscou 18(2): 132-157.

Desvaux, N.A. (1809) Observations sur quelques genres á établir dans la famille des champignons. Journal de Botanique (Desvaux) 2: 88-105.

Dissing, H. \& Lange, M. (1962) Gasteromycetes of Congo. Bulletin du Jardin Botanique de l'État à Bruxelles 32: 325416. http://dx.doi.org/10.2307/3667249

Donk, M.A. (1933) Revisie van de Nederlandse Heterobasidiomycetae en Homobasidiomycetae - Aphyllophoraceae I. Mededelingen van de Nederlandse Mycologische Vereeniging 18-20: 67-200.

Douanla-Meli, C., Langer, E. \& Calonge, F.D. (2005) Geastrum pleosporus sp. nov., a new species of Geastraceae identified by morphological and molecular phylogenetic data. Mycological Progress 4(3): 239-250. http://dx.doi.org/10.1007/s11557-006-0127-3

Felsenstein, J. (1985) Confidence limits on phylogenies: An approach using the bootstrap. Evolution 39: $783-791$. http://dx.doi.org/10.2307/2408678

Fitch, W.M. \& Margoliash, E. (1967) Construction of phylogenetic trees. Science 155: 279-284. http://dx.doi.org/10.1126/science.155.3760.279

Frey-Wyssling, A. (1981) Crystallography of the two hydrates of crystalline calcium oxalate in plants. American Journal of Botany 68(1): 130-141. http://dx.doi.org/10.2307/2443000

Fries, E. (1821) Systema mycologicum, vol. 1. Lund, LVII + 520 pp.

Fries, E. (1829) Systema mycologicum, vol. 3. Greifswald, VIII + 259 pp.

Fries, E. (1838) Epicrisis Systematis Mycologici, seu Synopsis Hymenomycetum. Uppsaliae, 610 pp.

Fries, E. (1863) Monographia Hymenomycetum Sueciae, vol. 2. C.A. Leffler, Uppsala, 355 pp.

Gilbertson, L., Lombard, F.F. \& Canfield, E.R. (1975) Guaiac gum in field tests for extracellular phenol oxidases of wood-rotting fungi and other basidiomycetes. USDA Forest Research Paper FPL 269: 1-23.

Gower, J.C. (1971) A general coefficient of similarity and some of its properties. Biometrics 27: 857-874. http://dx.doi.org/10.2307/2528823

Gray, S.F. (1821) A natural arrangement of British plants. Baldwin, Cradock and Joy, London, $824 \mathrm{pp}$.

Harkin, J.M. \& Obst, J.R. (1973) Syringaldazine, an effective reagent for detecting laccase and peroxidase in fungi. Experientia 29: 381-387. http://dx.doi.org/10.1007/bf01926734

Harkin, J.M., Larsen, M.J. \& Obst, J.R. (1974) Use of syringaldazine for detection of laccase in sporophores or wood rotting fungi. Mycologia 66(3): 469-476. http://dx.doi.org/10.2307/3758490

Hillis, D.M \& Bull, J.J. (1993) An empirical test of bootstrapping as a method for assessing confidence in phylogenetic analysis. Systematic Botany 42(2): 182-192.

Hollós, L. (1904) Die Gasteromyceten Ungarns. Oswald Weigel, Leipzig, 278 pp.

Horner, H.T., Tiffany, L.H \& Cody, A.M. (1985) Calcium oxalate bipyramidal crystals on the basidiocarps of Geastrum minus (Lycoperdales). The Proceedings of the Iowa Academy of Science 92(2): 70-77. 
Horner, H.T., Tiffany, L.H. \& Knaphus, G. (1995) Oak-leaf-litter rhizomorphs from Iowa and Texas: Calcium oxalate producers. Mycologia 87(1): 34-40.

http://dx.doi.org/10.2307/3760943

Jiménez-Mejías, P. \& Martinetto, E. (2013) Toward an accurate taxonomic interpretation of Carex fossil fruits (Cyperaceae): A case study in section Phacocystis in the Western Paleartic. American Journal of Botany 100(8): 1580-1603. http://dx.doi.org/10.3732/ajb.1200629

Junghuhn, F. (1840) Nova genera et species plantarum florae Javanicae. Tijdschrift voor Natuurlijke Geschiedenis en Physiologie 7: 285-317.

Karsten, P. (1890) Fragmenta mycologica XXIX. Hedwigia 29: 147-149.

Kasuya, T., Hosaka, K., Uno, K. \& Kakishima, M. (2012) Phylogenetic placement of Geastrum melanocephalum and polyphyly of Geastrum triplex. Mycoscience 53(6): 411-426. http://dx.doi.org/10.1007/s10267-012-0186-z

Keller, J. (1979) Ustrastructure des hyphes incrustées dans le genre Skeletocutis. Persoonia 10(3): 347-355.

Keller, J. (1985) Les cystides crystallifères des Aphyllophorales. Mycologia Helvetica 1(5): 277-340.

Kerrigan, R.W. (1986) The Agaricales (Gilled Fungi) of California. 6. Agaricaceae. Mad River Press Inc. Eureka, California, $62 \mathrm{pp}$.

Kirk, P.M., Cannon, P.F., Minter, D.W. \& Stalpers, J.A. (2008) Ainsworth and Bisby's Dictionary of the Fungi, $10^{\text {th }}$ edition. CABI Europe, UK, Wallingford, $771 \mathrm{pp}$.

Kitching, I.J., Forey, P.L., Humphries, C.J., Williams, D.M. (1998) Cladistics: the theory and practice of parsimony analysis. Oxford University Press, Oxford, New York, Tokyo.

Kotlaba, F. \& Pouzar, Z. (1958) Polypori novi vel minus cogniti Cechoslovakiae III. Ceská Mykologie 12(2): $95-104$.

Krisai, I. \& Mrazek, E. (1986) Calcium oxalate crystals in Geastrum. Plant Systematics and Evolution 154: $325-341$. http://dx.doi.org/10.1007/bf00990131

Lamarck, J.-B. \& de Candolle, A.P. (1805) Flore française, ou Descriptions succinctes de toutes les plantes qui croissent naturellement en France: disposées selon une nouvelle Méthode d'Analyse, et précédées par un Exposé des Principes élémentaires de la Botanique, vol. 2. Chez H. Agasse, Paris, 600 pp.

Largent, D.L. \& Benedict, R.G. (1970) Studies in the Rhodophylloid fungi II: Alboleptonia, a new genus. Mycologia 62(3): 437-452. http://dx.doi.org/10.2307/3757517

Larsson, K.-H. (1994) Poroid species in Trechispora and the use of calcium oxalate crystals for species identification. Mycological Research 98(10): 1153-1172. http://dx.doi.org/10.1016/s0953-7562(09)80200-1

Linnaeus, C. (1753) Species Plantarum. Salvius, Stockholm, 1200 pp.

Lloyd, C.G. (1901) Mycological Notes by C.G. Lloyd. No. 8. Mycological Writings 1: 73-78.

Lloyd, C.G. (1902) The Geastrae. Bulletin of the Lloyd Library of Botany, Pharmacy and Materia Medica 2: 1-43.

Maechler, M. Rousseeuw, P., Struyf, A., Hubert, M., Hornik, K. (2013) cluster: Cluster Analysis Basics and Extensions. $\mathrm{R}$ package version 1.14.4.

Marr, C.D. (1979) Laccase and tyrosinase oxidation of spot test reagents. Mycotaxon 9(1): 244-276.

Marr, C.D., Grund, D.W \& Harrison, K.A. (1986) The taxonomic potential of laccase and tyrosinase spot tests. Mycologia 78(2): 169-184. http://dx.doi.org/10.2307/3793162

Methven, A.S. (1990) The genus Clavariadelphus in North America. Bibliotheca Mycologica 138: 1-192.

Morgan, A.P. (1887) The genus Geaster. The American Naturalist 21: 1026-1029.

Morgan, A.P. (1895) New North American fungi. Journal of the Cincinnati Society of Natural History 18: 36-45.

Parra, L.A. (2008) Agaricus L. Allopsalliota Nauta \& Bas. I. Fungi Europaei 1: 1-824.

Pérez-Daniëls, P. (2002) Estudio biosistemático del orden Gomphales (Basidiomycota, Fungi) en la Península Ibérica. $\mathrm{Ph}$. D. [unpublished]. Universidad Complutense de Madrid.

Persoon, C.H. (1794) Neuer Versuch einer systematischen Einteilung der Schwämme. Neues Magazin für die Botanik 1: 63-128.

Persoon, C.H. (1795) Observationes mycologicae. Annalen der Botanik (Usteri) 15: 1-39.

Persoon, C.H. (1796) Observationes mycologicae, vol. 1. Wolf, Leipzig, 116 pp.

Persoon, C.H. (1801) Synopsis Methodica Fungorum. Göttingen, 106 pp.

Ponce de León, P. (1968) A Revision of the Family Geastraceae. Fieldiana. Botany 31(14): 301-349. http://dx.doi.org/10.5962/bhl.title.2389

Quélet, L. (1886) Enchiridion fungorum in Europae mediae et praesertim in Gallia virgentium. Lutetiae, Paris, 352 pp.

Rambaut, A. (2007) Molecular evolution, phylogenetics and epidemiology. FigTree. Available from: http:// tree.bio.ed.ac.uk/software/figtree/ (accessed: 1 Oct 2012).

Rick, J.E. (1906) Pilze aus Rio Grande do Sul (Brazilien). Brotéria. Série Botânica 5: 4-53. 
Sarnari, M. (1998) Monografia illustrata del Gènére Russula in Europa. Tomo Primo. AMB, Centro Studi Micologici, Trento, $800 \mathrm{pp}$.

Schweinitz, L.D. (1822) Synopsis fungorum Carolinae superioris. Schriften der Berlinische Gesellschaft Naturforschender Freunde 1: 20-131.

Singer, R. (1962) The Agaricales in modern taxonomy. Ed. 2. J. Cramer, Weinheim, 915 pp +75 pl.

Spegazzini, C. (1899, “1898”) Fungi Argentini novi vel critici. Anales del Museo de Historia Natural de Buenos Aires 6: 81-288.

Staněk, V.J. (1956) Hvezdovka Smardova - Geastrum smardae sp. n. Ceská Mykologie 10(1): 18-23.

Staněk, V.J. (1958) Geastraceae. In: A. Pilát (ed.) Flora ČSR B1, Gasteromycetes. Praha, pp. 392-526, 777-795.

Sunhede, S. (1986) Notes on the type material of Geastrum congolense. Windahlia 16: 113-122.

Sunhede, S. (1989) Geastraceae (Basidiomycotina). Morphology, ecology and systematics with special emphasis on the North European species. Synopsis Fungorum 1: 1-534.

Suzuki, R. \& Shimodaira, H. (2006) Pvclust: an R package for assessing the uncertainty in hierarchical clustering. Bioinformatics 22(12): 1540-1542. http://dx.doi.org/10.1093/bioinformatics/btl117

Swofford, D.L. (2003) PAUP*: Phylogenetic Analysis Using Parsimony (*and Other Methods), Version 4.0b10. Sunderland, Massachusetts: Sinauer Associates.

Tulloss, R.E. \& Rodríguez-Caycedo, C. (2011) Amanita Workshop, $6^{\text {th }}$ edition. New Jersey Mycological Association. Available from http://www.amanitaceae.org/content/uploaded/pdf/phenoxfm.pdf (accessed: 07 Feb 2013).

Vittadini, C. (1842) Monographia Lycoperdineorum. Torino, 93 pp.

Whitney, K.D. \& Arnott, H.J. (1986) Calcium oxalate crystals and basidiocarp dehiscence in Geastrum saccatum (Gasteromycetes). Mycologia 78(4): 649-656. http://dx.doi.org/10.2307/3807778

Zamora, J.C. \& Calonge F.D. (2007) Geastrum parvistriatum, una nueva especie encontrada en España. Boletín de la Sociedad Micológica de Madrid 31: 139-149.

Zeller, S.M. (1948) Notes on certain Gasteromycetes, including two new orders. Mycologia 40(6): 639-668. http://dx.doi.org/10.2307/3755316 
Appendix —List of studied specimens. For each specimen, we indicate the kind of data that were recorded, i.e., phenoloxidases spot tests [PST] or rhizomorphs features [RF].

Geastrum albonigrum Calonge \& M. Mata:-PANAMA. Isla de Coibas: Cerro de la X, sobre madera en descomposición, 14 November 1996, F. Pando \& M.P. Núñez (MA-Fungi 36140-2) [RF]. ECUADOR. Orellana: Parque Nacional Yasumi, al final de la senda, 6 April 2000, C. Lado (MA-Fungi 47194-2) [RF].

Geastrum arenarium Lloyd s.l::-SPAIN. Madrid: Villaviciosa de Odón, Urbanización Campodón, suelo arenoso, bajo Olea europaea, 6 November 2011, B. Zamora, herb. J.C. Zamora 498 [PST]. Ibidem, 12 November 2011, B. Zamora \& J.C. Zamora (herb. J.C. Zamora 499) [PST \& RF]. Ibidem, 28 December 2011, B. Zamora \& J.C. Zamora (herb. J.C. Zamora 500) [PST]. Ibidem, 21 October 2012, B. Zamora, J. Señoret \& J.C. Zamora (herb. J.C. Zamora 542) [PST \& RF].

Geastrum argentinum Speg.:-ARGENTINA. Buenos Aires: Partido de Berazategui, Pereyra, Pereyra Iraola park, Ligustrum lucidum implanted forest, 24 March 2012, V. Castiglia \& al. (MA-Fungi 82602) [PST \& RF]. Partido Lomas de Zamora, Llavallol, Santa Catalina, on rotten wood, 30 March 2012, E. Grassi, V. Castiglia, F. Kuhar \& J.C. Zamora (MA-Fungi 82603) [PST \& RF]. Ibidem, 12 May 2012, F. Kuhar \& J.C. Zamora (MA-Fungi 82604) [PST \& RF]. Ibidem, 12 May 2012, F. Kuhar \& J.C. Zamora (LPS 48446) [PST \& RF]. Salta: El Ucumar, Yungas, 10 April 2012, L. Papinutti, G. Rolón \& J.C. Zamora (MA-Fungi 82605) [PST \& RF].

Geastrum campestre Morgan.:-SPAIN. Madrid: Arroyomolinos, polígono industrial Valdefuentes, under Cedrus atlantica, 23 December 2006, B. Zamora \& J.C. Zamora, herb. J.C. Zamora 204 [RF]. Alcalá de Henares, under Pinus halepensis, calcareous soil, 20 November 2011, J.C. Zamora, J. Hernanz \& B. Zamora (herb. J.C. Zamora 502) [PST].

Geastrum congolense Dissing \& M. Lange:-CONGO. District Forestier Central: Eala, on the ground, September 1925, M. Goossens-Fontana 448bis (BR) [RF] [collection mixed with G. saccatum s.l. and one unidentified species of the "Myceliostroma group"].

Geastrum corollinum (Batsch.) Hollós:-SWEDEN. Öland: Köpngsvik, under Syringa, 29 August 2011, J.C. Zamora \& S.I. Sunhede (herb. Sunhede 7744) [RF].

Geastrum coronatum Pers.:-SPAIN. Madrid: Villaviciosa de Odón, park near the castle, under Ulmus minor and Pinus sp., 7 May 2011, B. Zamora, J. Señoret \& J.C. Zamora (herb. J.C. Zamora 484) [PST \& RF]. Ibidem, bajo Ulmus minor y Cupressus sempervirens, 13 November 2011, B. Zamora \& J.C. Zamora (herb. J.C. Zamora 549) [PST \& RF].

Geastrum elegans Vittad.:- SPAIN. Jaén: Montizón, Venta de los Santos, Cistus ladanifer and Quercus rotundifolia, 8 December 2012, B. Zamora, J. Señoret \& J.C. Zamora (herb. J.C. Zamora 533) [PST \& RF]. SWEDEN. Gotland: Ölbäck, under Pinus sylvestris, calcareous soil, 30 September 2011, E. Bohus Jensen \& J.C. Zamora (UPS F-560810) [PST].

Geastrum fimbriatum Fr.:-FRANCE. Aquitania: Osse-en-Aspe, Abies alba, 12 October 2012, G. Muñoz \& J.C. Zamora (herb. J.C. Zamora 569) [PST \& RF]. SPAIN. Huesca: Bielsa, valle de Pineta, bajo Abies alba, 13 October 2012, S. Català \& J.C. Zamora (herb. J.C. Zamora 564) [PST \& RF]. Ibidem, 13 October 2012, J.C. Zamora (herb. J.C. Zamora 565) [PST \& RF]. Ibidem, 13 October 2012, S. Català (herb. J.C. Zamora 566) [PST \& RF]. Ibidem, 13 October 2012, I. Garrido, S. Català \& J.C. Zamora (herb. J.C. Zamora 567) [PST \& RF]. Huesca, Villanúa, Fuente del Paco, bajo Abies alba, 10 October 2010, L.A. Parra (herb. J.C. Zamora 402) [PST \& RF]. Ibidem, 13 October 2012, S. Català (herb. J.C. Zamora 568) [PST]. Zaragoza: Moncayo, Pinus sylvestris, 27 October 2012, E. Soto \& J.C. Zamora (herb. J.C. Zamora 570) [PST \& RF]. Ibidem, 27 October 2012, E. Soto \& J.C. Zamora (herb. J.C. Zamora 571) [PST \& RF].

Geastrum floriforme Vittad.:-AUSTRALIA. Victoria: Neds Corner Station, Old Mail Rd, near 'dead kangaroo', 1$3 \mathrm{~m}$ off road to Routh. $34.1652777^{\circ} \mathrm{S} 141.3775^{\circ} \mathrm{E}$, mixed chenopod shrubland, on red sandy soil, $23 \mathrm{Nov}$. 2011, Lebel, $T$. 2412 (MEL 2358000) [RF].

Geastrum fornicatum (Huds.) Hook.:- SPAIN. Valladolid: Villanueva de Duero, encinar de Quercus rotundifolia, arenoso, sombrío y húmedo, con abundante y gruesa capa de humus, 2 November 2007, G. Martínez Fernández \& A. García Blanco (herb. J.C. Zamora 255) [RF].

Geastrum hariotii Lloyd s.l.:-BRAZIL. Santa Catarina: Trilha da Pedra do Urubu, 31 May 2007, E. Fazolino (MAFungi 79065) [RF].

Geastrum hieronymi Henn.:-ARGENTINA. Córdoba: Traslasierra, La Población, under Prosopis sp., 2 April 2012, leg. J.C. Zamora, E. García \& A. Arambarri (MA-Fungi 83766) [RF].

Geastrum kotlabae V.J. Staněk.:-SPAIN. Ávila: Navaluenga, bajo Pinus pinaster, suelo arenoso, 1 December 2011, J. De Esteban, T. De Esteban \& J.C. Zamora (herb. J.C. Zamora 532) [PST \& RF].

Geastrum lageniforme Vittad. s.l.:-ARGENTINA. Entre Ríos: Colón, Ubajay, El Palmar, marginal forest, 1 June 2012, J. Maller \& J.C. Zamora (MA-Fungi 83768) [PST \& RF]. Ibidem, marginal forest, 2 June 2012, S. Suaza \& J.C. Zamora (MA-Fungi 83769) [PST \& RF]. Misiones: Oberá, Campo Ramón, marginal forest, 13 June 2012, E. Grassi \& 
J.C. Zamora (MA-Fungi 83770) [PST \& RF]. PORTUGAL. Madeira: Ribeiro Frío, laurisilva, 22 October 2008, F.D. Calonge \& al. (MA-Fungi 78398) [RF]. SPAIN. Madrid: Alcalá de Henares, bajo Pinus halepensis, suelo calizo, 20 November 2011, J. Hernanz, B. Zamora \& J.C. Zamora (herb. J.C. Zamora 537) [PST \& RF]. Ibidem, 25 November 2011, B. Zamora \& J.C. Zamora (herb. J.C. Zamora 563) [PST \& RF]. Villaviciosa de Odón, urbanización Campodón, bajo Olea europaea, suelo arenoso, 21 October 2012, B. Zamora \& J.C. Zamora (herb. J.C. Zamora 562) [PST]. Toledo: bajo Quercus rotundifolia, 11 November 2012, J. De Esteban, B. Zamora \& J.C. Zamora (herb. J.C. Zamora 538) [PST \& RF].

Geastrum melanocephalum (Czern.) V.J. Staněk:-SPAIN. Huesca: Panticosa, Fagus sylvatica, 31 September 2012, F. Serrano (herb. J.C. Zamora 557) [PST]. SWEDEN. Uppland: Uppsala parish, close to the hospital, under bushes, 15 September 2011, S. Ryman \& J.C. Zamora (MA-Fungi 86666) [PST]. Uppsala parish, Vårdsätra, NNV om Ekolsnäs, Quercus robur, 15 September 2011, S. Ryman, S. Ekman \& J.C. Zamora (MA-Fungi 86667) [PST \& RF]. Ibidem, 23 September 2011, S. Ryman \& J.C Zamora (MA-Fungi 86668) [PST \& RF].

Geastrum minimum Schwein. s.l.:-SPAIN. Madrid: Alcalá de Henares, bajo Pinus halepensis, suelo calizo superficialmente quemado, 20 November 2011, J. Hernanz, B. Zamora \& J.C. Zamora (herb. J.C. Zamora 550) [PST \& RF]. SWEDEN. Gotland: Holmhällar (close to the hotel), open area on sandy soil, among lichens, mosses and grasses, not far away from Pinus sylvestris, 28 September 2011, J.C. Zamora, M. Jeppson \& M. Lathi (MA-Fungi 86669) [PST].

Geastrum morganii Lloyd s.l.:-ARGENTINA. Entre Ríos: Colón, Ubajay, El Palmar, marginal forest, 1 June 2012 , S. Suaza \& J.C. Zamora (MA-Fungi 83772) [PST \& RF]. Salta: La Candelaria, Palo Quemado, Yungas, 12 April 2012 , L. Papinutti, J.C. Zamora \& G. Rolón (MA-Fungi 83773) [PST \& RF]. SPAIN. Asturias: Gozón, playa de Xagó, en suelo arenoso de retroduna fijada por Eucalyptus globulus, 25 February 2012, A. Román Vargas (herb. J.C. Zamora 525) [RF].

Geastrum ovalisporum Calonge \& Mor.-Arr.:-ARGENTINA. Salta: La Candelaria, Palo Quemado, Yungas, 12 April 2012, L. Papinutti, G. Rolón \& J.C. Zamora (MA-Fungi 86670) [PST \& RF].

Geastrum parvistriatum J.C. Zamora \& Calonge:-SPAIN. Madrid: Ciudad Universitaria, en frente del Instituto Anatómico Forense, bajo Cupressus arizonica var. bonita, 19 October 2012, J.C. Zamora, C. Galán \& L. Zhang (herb. J.C. Zamora 539) [PST \& RF]. Alcalá de Henares, bajo Pinus halepensis, suelo calizo, 15 November 2011, B. Zamora \& J.C. Zamora (herb. J.C. Zamora 551) [PST \& RF].

Geastrum pectinatum Pers.:-ARGENTINA. Buenos Aires: partido Lomas de Zamora, Llavallol, Santa Catalina, Ligustrum lucidum implanted forest, 12 May 2012, F. Kuhar, V. Castiglia, E. Grassi \& J.C. Zamora (MA-Fungi 83774) [PST]. SPAIN, Madrid, E.T.S.I. de Montes, bajo Cupressus sp., 22 November 2005, J.C. Zamora (herb. J.C. Zamora 118) $[\mathrm{RF}]$.

Geastrum pleosporum Douanla-Meli:-CAMEROON. Mbalmayo: Mbalmayo Forest Reserve, en restos vegetales y madera descompuesta de Triplochiton scleroxylon, 16 October 2002, C. Douanla-Meli (MA-Fungi 56971) [RF].

Geastrum pseudolimbatum Hollós:-SPAIN. Cádiz: a unos $6 \mathrm{~km}$ de la costa, bajo Eucalyptus sp., suelo arenoso, 13 April 2007, I. Frutos (herb. J.C. Zamora 230) [RF].

Geastrum quadrifidum Pers.: Pers:-SPAIN. Huesca: Bielsa, valle de Pineta, bajo Abies alba, 13 October $2012, J$. Hernanz (herb. J.C. Zamora 561) [PST \& RF]. SWEDEN. Uppland: Älkarleby, Billuddens naturreservat, under Pinus sylvestris, Picea abies, and Betula pendula, on sandy, calcareous soil, 15 October 2011, I. Olariaga \& J.C. Zamora (MAFungi 86671) [PST \& RF].

Geastrum rufescens Pers. : Pers.:-SPAIN. Huesca: Aísa, bajo Pinus sylvestris, 10 October 2010, B. Zamora \& J.C. Zamora (herb. J.C. Zamora 399) [PST]. Panticosa, Fagus sylvatica, 31 September 2012, F. Serrano (herb. J.C. Zamora 556) [PST]. Madrid: San Martín de Valdeiglesias, bajo Cupressus arizonica var. bonita, 27 November 2011, J. Señoret, B. Zamora, J.C. Zamora, A. Martínez, I. Liberal, A. Quiroga, M. Fernández-Mazuecos \& J.L. Blanco (herb. J.C. Zamora 543) [PST].

Geastrum saccatum Fr. s.l:--ARGENTINA. Buenos Aires: Partido de Berazategui, Pereyra, Pereyra Iraola park, Ligustrum lucidum implanted forest, 17 March 2012, G. Rolón, L. Papinutti \& J.C. Zamora (MA-Fungi 83775) [PST \& RF]. Entre Ríos: Colón, Ubajay, El Palmar, marginal forest, 1 June 2012, S. Suaza \& J.C. Zamora (MA-Fungi 83776) [PST \& RF]. Ibidem, 2 June 2012, J. Maller \& J.C. Zamora (MA-Fungi 83777) [PST \& RF]. Salta: La Candelaria, Yungas, 11 April 2012, L. Papinutti, J.C. Zamora \& G. Rolón (MA-Fungi 83778) [PST \& RF]. BOLIVIA. Concepción: Piedra de Santa Teresita, en claros de bosque tropical, sobre suelo arenoso con abundantes restos vegetales en descomposición, 5 March 2000, B. Moreno-Arroyo \& J. Gómez (MA-Fungi 47185-2) [RF]. CONGO. District Forestier Central: Eala, on the ground, September 1925, M. Goossens-Fontana 448bis (BR) [RF] [collection mixed with G. congolense and one unidentified species of the "Myceliostroma group"]. SPAIN. Madrid: Boadilla del Monte, bajo Populus alba, Crategus monogyna y Ulmus minor, 5 January 2013, J. Hernanz, J.C. Campos, E. Sanz \& J.C. Zamora (herb. J.C. Zamora 536) [PST \& RF]. Toledo: bajo Quercus rotundifolia, 1 November 2012, J. De Esteban (herb. J.C. 
Zamora 535) [RF]. VENEZUELA. Monagas: cerca de la Cueva del Guácharo, suelo con abundantes restos vegetales, 2 August 1990, F.D. Calonge (MA-Fungi 34138) [RF].

Geastrum schmidelii Vittad.:-SPAIN. Madrid: Colmenarejo, bajo Juniperus oxycedrus, 28 December 2012 , F. Prieto, Á. González \& J.C. Zamora (herb. J.C. Zamora 546) [PST \& RF]. San Martín de Valdeiglesias, bajo Cupressus arizonica, suelo silíceo, 5 January 2008, J.C. Zamora \& J.C. Campos (herb. J.C. Zamora 279) [RF]. Ibidem, 15 December 2012, F. Durán, A. Martínez, E. Cano, J.V. Sandoval \& J.C. Zamora (herb. J.C. Zamora 548) [PST \& RF]. SWEDEN. Gotland: Holmhällar (close to the hotel), open area on sandy soil, among lichens, mosses and grasses, not far away from Pinus sylvestris, 28 September 2011, J.C. Zamora, M. Jeppson \& M. Lathi (UPS F-560809) [PST].

Geastrum schweinitzii (Berk. \& M.A. Curtis) Zeller s.l:-ARGENTINA. Misiones: Puerto Iguazú, Paranaense forest, 2011, E. Grassi (MA-Fungi 83779) [RF]. Jujuy: El Carmen, Yungas, 13 April 2012, G. Rolón, L. Papinutti \& J.C. Zamora (MA-Fungi 83780) [PST \& RF]. COSTA RICA. Guanacaste: Parque Nacional Palo Verde, sendero La Venada, 12 October 2004, I. López 6202 (MA-Fungi 65464) [RF]. Las Mellizas, 29 August 2005, E. Navarro 9452 (MA-Fungi 65441) [RF]. PANAMA. Isla de Coibas: Cerro de la X, 14 November 1996, sobre madera en descomposición, F. Pando \& M.P. Núñez (MA-Fungi 36140-1) [RF]. Entre playa Blanca y Barco Quebrado, bosque inundado de Prioria copaifera, madera en descomposición, 15 November 1996, F. Pando \& M.P. Núñez (MA-Fungi 36141) [RF]. VENEZUELA. Sucre: San Juan de Macarapana, sobre madera muerta, 25 April 1990, L. Verde de Millán (MA-Fungi 34130) [RF].

Geastrum setiferum Baseia:-ARGENTINA. Entre Ríos: Colón, Ubajay, El Palmar, marginal forest, 2 June 2012, S. Suaza \& J.C. Zamora (MA-Fungi 83782) [PST \& RF].

Geastrum sp. ("Myceliostroma group"):-CONGO. District Forestier Central: Eala, on the ground, October 1925, M. Goossens-Fontana 448bis (BR) [RF] [collection mixed with G. congolense and G. saccatum s.l.].

Geastrum striatum DC.:-SPAIN. Madrid: E.T.S.I. de Montes, bajo Pinus halepensis, 9 January 2007, J.C. Zamora (herb. J.C. Zamora 212) [RF]. Ibidem, bajo Cupressus sp., Mahonia aquifolium, Pinus sp. y otras plantas, 9 October 2007, J.C. Zamora (herb. J.C. Zamora 250) [RF]. Ibidem, bajo Cupressus sp., 18 October 2012, J.C. Zamora, L. Zhang \& C. Galán (herb. J.C. Zamora 540) [RF]. Ibidem, bajo Pinus halepensis, 18 October 2012, C. Galán, L. Zhang \& J.C. Zamora (herb. J.C. Zamora 541) [PST \& RF]. SWEDEN. Uppland: Uppsala, humus of Abies sp., 23 October 2011, J.C. Zamora (MA-Fungi 86672) [PST].

Geastrum triplex Jungh. s.l.:-ARGENTINA. Catamarca: Paclín, La Merced, Yungas, 10 April 2012, L. Papinutti, J.C. Zamora \& G. Rolón (MA-Fungi 83784) [PST \& RF]. SPAIN. Jaén: Montizón, Venta de los Santos, cerca del embalse del río Dañador, bajo Pinus pinea, 5 December 2011, J.C. Zamora, J. Señoret \& B. Zamora (herb. J.C. Zamora 544) [PST]. Ibidem, J.C. Zamora, J. Señoret \& B. Zamora (herb. J.C. Zamora 545) [PST]. Huesca: Panticosa, Fagus sylvatica, 31 September 2012, F. Serrano (herb. J.C. Zamora 558) [PST]. Bielsa, valle de Pineta, Abies alba y Pinus sylvestris, 13 October 2012, J.C. Zamora (herb. J.C. Zamora 559) [PST \& RF]. Ibidem, 13 October 2012, A. Sierra \& J.C. Zamora (herb. J.C. Zamora 560) [PST \& RF]. Toledo: Santa Cruz de la Zarza, bajo Quercus rotundifolia, suelo calizo, 18 November 2011, B. Zamora \& J.C. Zamora (herb. J.C. Zamora 552) [PST \& RF]. Madrid: San Martín de Valdeiglesias, bajo Quercus rotundifolia, 27 November 2011, B. Zamora, J.C. Zamora, J. Señoret, A. Martínez, J.L. Blanco, I. Liberal, A. Quiroga \& M. Fernández-Mazuecos (herb. J.C. Zamora 553) [PST]. Ibidem, bajo Cupressus arizonica var. bonita, 27 November 2011, B. Zamora, J. Señoret, J.C. Zamora, A. Martínez, M. Fernández-Mazuecos, A. Quiroga, J.L. Blanco \& I. Liberal (herb. J.C. Zamora 554) [PST].

Geastrum velutinum Morgan s.l.:-ARGENTINA. Entre Ríos: Colón, Ubajay, El Palmar, marginal forest, 2 June 2012, S. Suaza \& J.C. Zamora (MA-Fungi 83785) [PST \& RF]. Misiones: Oberá, Campo Ramón, Paranaense forest, 11 June 2012, E. Grassi \& J.C. Zamora (MA-Fungi 83786) [PST \& RF]. BRAZIL. Rio Grande do Norte: Mata Estrela, March 2006, I. Baseia (MA-Fungi 78294) [RF]. INDIA. Uttaranchal: Nainital, Mukteshwar, 2220 m, 15 September 2004, D. Bischt (MA-Fungi 73247) [RF]. PERU. Cuzco: Santa María, Amazon rainforest, 1 May 2012, L. Papinutti, G. Rolón \& J.C. Zamora (MA-Fungi 83787) [PST \& RF]. VENEZUELA. Nueva Esparta: Isla de Margarita, entre hojarascas, 23 July 1990, F.D. Calonge (MA-Fungi 34133) [RF].

Geastrum violaceum Rick:- ARGENTINA. Corrientes: Curuzú Cuatiá, sobre hojarasca de Nectrandra sp., May 2007, L. Papinutti (BAFC 15671) [RF]. Misiones: Iguazú, Puerto Iguazú, Paranaense forest, 10 June 2012, E. Grassi \& J.C. Zamora (MA-Fungi 8487) [PST \& RF]. Oberá, Campo Ramón, Paranaense forest, 11 June 2012, E. Grassi \& J.C. Zamora (MA-Fungi 8488) [PST \& RF]. Salta: La Candelaria, Palo Quemado, Yungas, 12 April 2012, G. Rolón, L. Papinutti \& J.C. Zamora (MA-Fungi 8489) [PST \& RF]. Ibidem, 12 April 2012, G. Rolón, L. Papinutti \& J.C. Zamora (MA-Fungi 8490) [PST \& RF]. Ibidem, 12 April 2012, G. Rolón, L. Papinutti \& J.C. Zamora (MA-Fungi 8491) [PST \& $\mathrm{RF}]$. 